\title{
RELATIVE RATES OF PHOTOSYNTHESIS AND STANDING STOCK OF THE NET PHYTOPLANKTON AND NANNOPLANKTON
}

(Received 11/11/63)

\section{Teixeira}

\section{INTRODUCTION}

Some researches, beginning with Gran (1932), Steemann Nielsen (1938; 1957), Riley (1941), Harvey (1950), Wood \& Davis (1956), Yentsch \& Ryther (1959), Teixeira \& Kutner (1962) and others, showed that many phytoplankton species in most regions of the oceans are too small to be retained by the finest silk plankton nets.

Based on the size of the organisms, the phytoplankton is generally divided into two principal groups: nannoplankton and net phytoplankton (= microplankton), and sometimes a third group: ultraplankton. The size limits of these groups are approximately the following: 10 to $50 \mu$ (nannoplankton), 50 to $500 \mu$ (net phytoplankton) and 0.5 to $10 \mu$ for the ultraplankton (Strickland, 1960).

All the observations agree entirely on the importance of the nannoplankton in the production of organic matter in the oceans, but knowledge on the quantitative relationship between nanno and net phytoplankton in most regions of the oceans is still very scarce.

The primary purpose of this paper is to verify the importance of nannoplankton in relation to the total phytoplankters and the differences which exist between environments of coastal and oceanic waters in an Equatorial region (Fig. 1).

For this purpose, the Carbon-14 technique was used to determine the relative photosynthesis and cell counts were made to determine the relative standing stock.

The field work was undertaken on board of the destroyer "Bertioga" between 20 and 23 March 1963, during the "Equalant

Publ. ne 191 do Inst. Ocean. da USP. 
Expedition" of the International Cooperative Investigations of the Tropical Atlantic (ICITA).

The samples were taken from the surface and poured through a silk plankton net (aperture size $=65 \mu$ ) to separate the net phytoplankton from the nannoplankton. Equal aliquots of the filtered samples and raw water samples were taken for photosynthesis measurements and cell counting.

The carbon fourteen uptake was determined in a $125 \mathrm{ml}$ bottle, using 10 microcuries ( $\mu$ C) of C-14, and incubating each sample for 2-4 hours in the shipboard incubator at the sea-surface temperature, and exposed to solar radiation. The temperature in the bath showed some fluctuation but never exceeded that of the seasurface temperature by more than $2.0^{\circ} \mathrm{C}$ during the experimental time, and usually less.

The incubated samples were filtered through AA-millipore filters, which were dried in a dessicator and subsequently treated with hydrochloric acid vapour to remove any inorganic carbonate activity from the filtered phytoplankton.

The radio-activity was measured with an end-window GeigerMüller counter tube (Phillips Equipment), and the results obtained have not been corrected for isotope effect nor phytoplankton respiration, since the values are only relative.

For the counting of the cell number, the plankton was preserved in neutral formalin and was allowed to settle overnight in a $20 \mathrm{ml}$ cylindrical chamber. Counts were made at 400 and $1,000 \times$ with a Zeiss inverted microscope.

\section{RESULTS AND DISCUSSION}

Only a few years ago (Holmes, 1956; Steemann Nielsen \& Jensen, 1957; and Yentsch \& Ryther, 1959) investigations were made to verify the relative importance of nanno and net phytoplankton in natural waters in terms of relative rates of photosynthesis.

For this purpose some measurements were carried out in Equatorial waters, and the results of these experiments showed a pronounced difference between nanno and net phytoplankton, not only in photosynthetic terms, but in cell numbers as well.

It should be noted that the uptake values for nannoplankton, probably may be underestimated when we consider that some damage of the photosynthetic capacity may occur during filtration (Steemann Nielsen \& Jensen, 1957). 
From the figures obtained (Table I) it may be seen that the organisms retained by the silk represent an average of only $9.93 \%$ in terms of photosynthesis and $22.20 \%$ in numbers of organisms of the total phytoplankton. However the term total phytoplankton must be used with some reserve in particular for tropical waters, if we consider Holmes' data (1956). This paper indicates that losses of ultraplankton may be serious unless filters with pore size of less than $0.5 \mu$ are used; the author believes that the bulk of photosynthesizing organisms falls between 1-30 $\mu$ (Holmes, 1956).

From the values found here as well as those reported by different authors and from different regions sampled, it can be shown that the nannoplankton elements play a more important role in the production of matter in the oceans than the larger cells. Some authors (Atkins, 1945; Wood \& Davis, 1956; and others) have claimed greater importance for autotrophic flagellates but unfortunatelly we do not know what fraction of the nannoplankton is composed of $\mu$-flagellates, diatoms or other small autotrophic and heterotrophic organisms.

Recently Collier \& Murphy (1962) were able to isolate several species and genera of small diatoms: some organisms, considering individual cells, have a diameter of $0.75 \mu$; one species of Chaetoceros measured $1.5 \mu$ (apical axis) by $3.0 \mu$ (pervalvar axis). The existence of diatom populations of cells of such size can modify at least partially the concepts of Atkins (1945), Wood \& Davis (1956) and others. The lack of methods for separating the different components of the community designated nannoplankton makes it impossible to evaluate this suggestion at the present time.

The results obtained by several authors show clearly that the larger percentages of net phytoplankton were found in eutrophic oceanic waters, e.g. arctic waters (Digby, 1953). In contrast to this, oligotrophic waters, for example, in the north Central Sargasso Sea (Riley, 1957), the Sargasso Sea off Bermuda (Hulburt, Ryther \& Guillard, 1960), in the Sargasso Sea (Steemann Nielsen \& Jensen, 1957) and in Equatorial waters off northern Brazil (Table I), demonstrate the small percentage of the net phytoplankton.

Although the total primary production of these oligotrophic regions is very low, the nannoplankton is, in relative terms, generally more important than in the rich waters.

Waters characterized by small quantities of nutrients, become more favourable to small rather than larger organisms, because of the high surface-to-volume ratio present in small cells. According to Collier \& Murphy (1962) the populations of small organisms 
in the environment may be significant, because of the power of intense utilization of nutrients and the capability for rapid multiplication even under minimal nutrient concentration conditions.

TABLE I

\begin{tabular}{|c|c|c|c|c|c|c|c|}
\hline \multirow{2}{*}{$\begin{array}{l}\text { Sta. } \\
\text { No. }\end{array}$} & \multirow{2}{*}{ Date } & \multirow{2}{*}{ Latitude } & \multirow{2}{*}{ Longitude } & \multicolumn{2}{|c|}{$\begin{array}{c}\text { Relative } \\
\text { photosynthesis }\end{array}$} & \multicolumn{2}{|c|}{$\begin{array}{c}\text { Relative } \\
\text { standing stock }\end{array}$} \\
\hline & & & & $\begin{array}{l}\text { Nanno- } \\
\text { plankton }\end{array}$ & $\begin{array}{c}\text { Net } \\
\text { Phyto- } \\
\text { plankton }\end{array}$ & $\begin{array}{c}\text { Nanno- } \\
\text { plankton }\end{array}$ & $\begin{array}{c}\text { Net } \\
\text { Phyto- } \\
\text { plankton }\end{array}$ \\
\hline 1 & $22 / 3 / 63$ & $04^{\circ} 06.3 \mathrm{~N}$ & $44044.0 \mathrm{~W}$ & 87.00 & 13.00 & 71.50 & 28.50 \\
\hline 2 & $22 / 3 / 63$ & $03^{\circ} 02.0 \mathrm{~N}$ & $45^{\circ} 21.0 \mathrm{~W}$ & 88.30 & 11.70 & 73.70 & 26.30 \\
\hline 3 & $22 / 3 / 63$ & $01^{\circ} 05.0 \mathrm{~N}$ & $46^{\circ} 23.8 \mathrm{~W}$ & 90.60 & 9.40 & 77.90 & 22.10 \\
\hline 4 & $23 / 3 / 63$ & $00^{\circ} 39.8 \mathrm{~N}$ & $46038.0 \mathrm{~W}$ & 89.00 & 11.00 & 78.00 & 22.00 \\
\hline 5 & $23 / 3 / 63$ & $00^{\circ} 03.0 \mathrm{~N}$ & $46^{\circ} 59.0 \mathrm{~W}$ & 91.60 & 8.40 & 82.70 & 17.30 \\
\hline 6 & $23 / 3 / 63$ & $00017.3 \mathrm{~s}$ & $47^{\circ} 10.6 \mathrm{~W}$ & 93.60 & 6.10 & 83.00 & 17.00 \\
\hline
\end{tabular}

Phytoplankton standing stock and C-14 uptake by net phytoplankton and nannoplankton from surface sea-water samples collected in Equatorial waters.

TABLE II

\begin{tabular}{c|c|c|c}
\hline Sta. No. & $\begin{array}{c}\text { Distance from the } \\
\text { coast (in miles) }\end{array}$ & $\begin{array}{c}\text { Relative production } \\
\text { (C-14 uptake) }\end{array}$ & $\begin{array}{c}\text { No. of cells per liter } \\
\text { (in per cent) }\end{array}$ \\
\hline 1 & 325 & 5.30 & 7.60 \\
2 & 255 & 5.30 & 12.00 \\
3 & 120 & 7.90 & 10.20 \\
4 & 80 & 18.40 & 15.60 \\
5 & 55 & 91.80 & 82.50 \\
6 & 20 & 100.00 & 100.00 \\
\hline
\end{tabular}

Relative values showing the variation of C-14 uptake and cell numbers at the six stations from coastal waters to open sea. The greatest rate of the C-14 uptake and cell number is put at $100 \%$. 
The relative photosynthesis measurements in coastal and in oceanic waters show the effect of the proximity of land which was also apparent on the standing stock.

Many papers have reported the "land-mass" effect as an increase of phytoplankton standing stock, but primary productivity measurements are scarce. The results presented in this paper show a consistent increase as we approach land. A comparison of the magnitude of the production of the station near to the coast (Station 6; Table II) to the station farther from the coast (Station 1; Table II) shows a higher rate of total carbon fixed and a larger standing stock of phytoplankton in coastal waters than exists at the station located 300 miles offshore, where the rate of carbon fixation and the population stock were very low.

However these measurements can indicate only a general picture of photosynthetic potential of two different water masses, since only the productivity index can really show if a certain area is more or less productive than other.

The increase landwards has been attributed by many authors to upwelling, different salinity, nutrient properties of the water, inorganic and organic growth substances, temperature and other factors, but at present, the question whether or not the net primary productivity as well as the primary product is greater at inshore locations (see Strickland's discussions, 1960) is still an open problem.

\section{S U M M A R Y}

Some experiments on $\mathrm{C}-14$ uptake and cell numbers were made with the purpose of comparing nannoplankton and net phytoplankton from surface sea-water samples collected at six stations in Equatorial waters (Fig. 1).

The results of these experiments showed a pronounced difference between nanno and net phytoplankton in photosynthesis and in cell numbers (Table I). The net phytoplankton represents an average of as little as $9.93 \%$ of total photosynthesis and $22.20 \%$ in numbers of organisms of total phytoplankton.

The results obtained in coastal and in oceanic waters show that the effect of the proximity of land on standing stock and upon primary production is well marked (Table II). papers.

The results obtained are discussed and compared with data of earlier

\section{RES UMO}

O autor teve como principal escopo ao levar a efeito esta série de experimentos, verificar a importância relativa de duas frações obtidas artificialmente do fitoplâncton natural, o nanoplâncton e a fração retida por uma rêde (Teixeira \& Kutner, 1962).

As amostras foram coletadas em seis estações a partir das proximidades da costa norte do Brasil até cêrca de 300 milhas para fora. Tôdas as amos- 
tras foram coletadas na superfície e a seguir separadas em duas porções; uma parte foi filtrada numa rêde de sêda com poros de $65 \mu$ de diâmetro para reter o "net" fitoplâncton e a outra permaneceu intacta, constituindo-se na amostra do plâncton total; a diferença de valôres obtida entre as duas porções constitui o nanoplâncton.

Para a determinação da fotossíntese, foi usado o método do Carbono 14 (Steemann Nielsen, 1952) e para avaliar o estoque das algas foi adotado o método de contagem de organismos ao microscópio invertido, após a sedimentação por 24 horas.

Todos os resultados obtidos foram apresentados em percentagens, por serem muito mais representativos do que se fôssem apresentados como absolutos.

Dos resultados experimentais, podemos verificar uma pronunciada diferença quantitativa dinâmica e estática entre o nanoplâncton e o "net" fitoplâncton (Tabela I), assim como uma grande diferença quanto ao estoque e à produção do fitoplâncton existente em águas costeiras e oceânicas (Fig. 1).

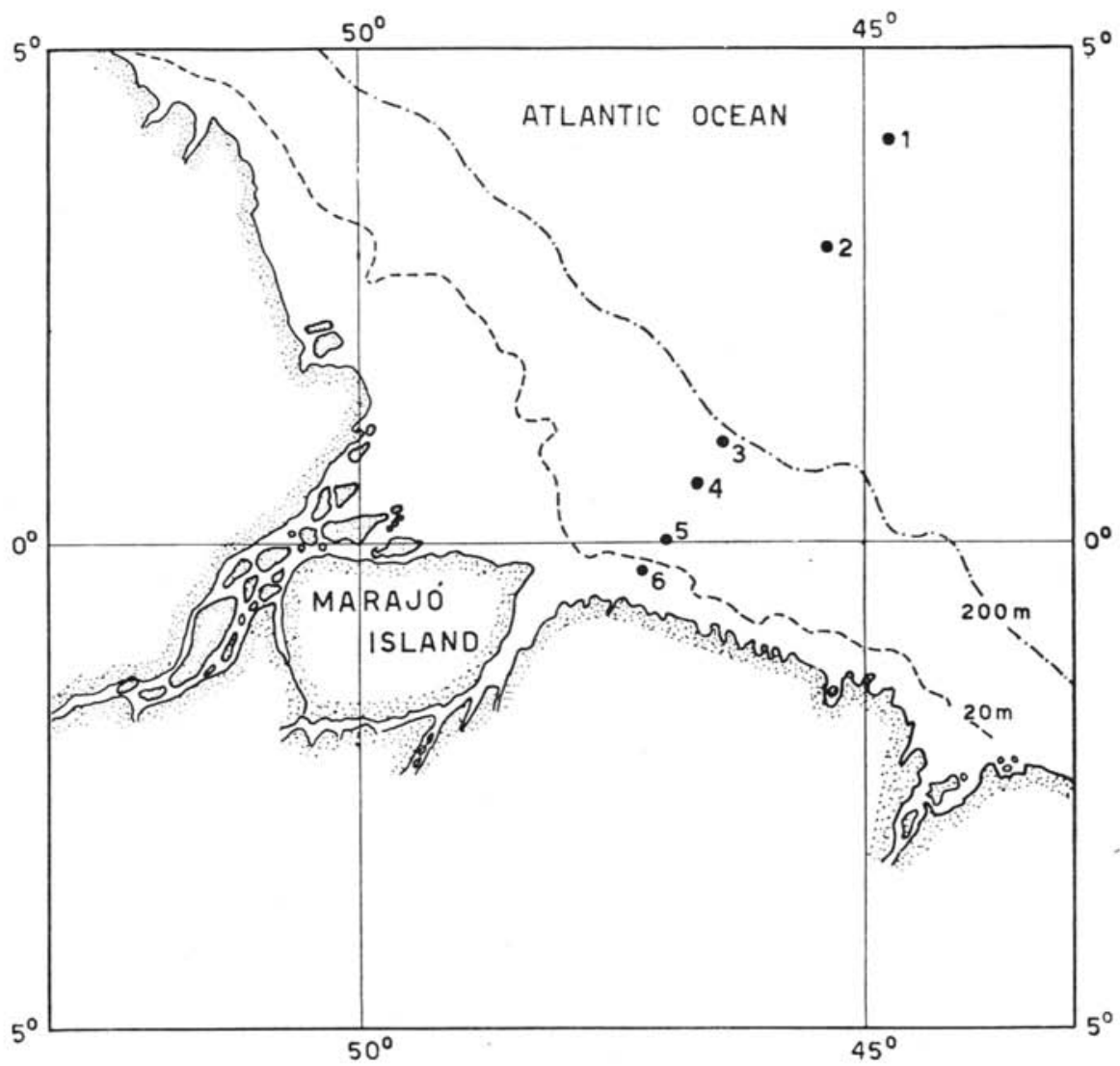

Fig. 1 - The position of the stations cited in the text. 


\section{ACKNOWLEDGEMENTS}

The author wishes to express the best thanks to Dr. Marta Vannucci and to Dr. Robert W. Holmes by the appreciation and suggestions in preparing the manuscript; and to the "Fundação de Amparo à Pesquisa do Estado de São Paulo" for the grant awarded to the author.

\section{R E F E R E N C E S}

AtKins, W. R. G.

1945. Autotrophic flagellates as the major constituent of the oceanic phytoplankton. Nature, Lond., n. ${ }^{\circ} 156$, p. 446.

Collier, A. \& Murphy, A.

1962. Very small diatoms: preliminary notes and description of Chaetoceros galvestonensis. Science, vol. 136, n.? 3.518, p. 780-782.

DigBy, P. S. B.

1953. Plankton production in Scoresby Sound, East Greenland. Jour. Anim. Ecol., vol. 22, p. 289-322.

GrAN, H. H.

1932. Phytoplankton. Methods and problems. Jour. Cons., vol. VII, n. ${ }^{\circ} 3$, p. $343-358$.

HARVEY, H. W.

1950. On the production of living matter in the sea off Plymouth Jour. Mar. Biol. Assoc. U.K., vol. 29, p. 97-137.

Holmes, R. W.

1959. Size fractionation of photosynthesizing phytoplankton. Fish. \& Wildl. Serv., Special Sci. Rep., Fish. n. ${ }^{\circ}$ 279, p. 69-71.

Hulburt, E. M., Ryther, J. H. \& Guillard, R. R. L.

1960. The phytoplankton of the Sargasso Sea off Bermuda. Jour. Cons., vol. 25 n. $^{\circ} 2$, p. $115-128$.

RILEY, G. A.

1941. Plankton studies. III. Long Island Sound. Bull. Bingham Oceanogr. Coll., vol. 7 , n. ${ }^{\circ}$ 3, p. 1-93.

1957. Phytoplankton of the north central Sargasso Sea. Limnol. \& Oceanogr., vol. 2, p. 252-270.

Steemann Nielsen, E.

1938. Über die Anwendung von Netzfängen bei quantitativen Phytoplanktonuntersuchungen. Jour. Cons., vol. 13, n. ${ }^{\circ}$ 2, p. 197.

1952. The use of radio-active Carbon $\left(\mathrm{C}^{14}\right)$ for measuring organic production in the sea. Jour. Cons., vol. 18, n. ${ }^{\circ}$, p. 117-140. 
Steemann Nielsen, E. \& Jensen, E. A.

1957. Primary oceanic production. The autotrophic production of organic matter in the aceans. Galathea Rep., vol. 1, p. 49136.

Strickland, J. D. H.

1960. Measuring the production of marine phytoplankton. Fish. Res. Board Canada, Bull. n. ${ }^{\circ}$ 122, 172 p.

Teixeira, C. \& Kutner, M. B.

1962. Plankton studies in a mangrove environment. I. First assessment of standing stock and principal ecological factors. Bol. Inst. Ocean, vol. 12, n. $^{\circ}$ 3, p. 101-124.

Woop, E. J. F. \& Davis, P. S.

1956. Importance of smaller phytoplankton elements. Nature, Lond., vol. 177 , p. 438 .

Yentsch, C. S. \& RYtheR, J. H.

1959. Relative significance of the net phytoplankton and nannoplankton in the waters of Vineyard Sound. Woods Hole Ocean. Instit., Coll. Rep. Contr. n. ${ }^{\circ} 984$. 